\title{
ON JURIES AND DAMAGE AWARDS: THE PROCESS OF DECISIONMAKING
}

\author{
Edith Greene* \\ I \\ INTRODUCTION
}

In 1985 , a twelve-person Baltimore jury awarded Debra Sterling $\$ 25,000$ in compensatory damages and $\$ 1,501,000$ in punitive damages after she had been handcuffed and thrown to the ground outside a drug store by a security guard who believed that she had shoplifted a $\$ 1.49$ soda. ${ }^{1}$ The trial lasted for approximately two weeks during which time medical and psychiatric experts testified about the physical and emotional damages suffered by the plaintiff. The jury took one and a half hours to decide liability and compensatory damages in favor of Ms. Sterling; after a second trial for punitive damages, the jury deliberated eight and a half minutes before returning verdicts of $\$ 1000$ against the security guard and $\$ 1,500,000$ against his employer, Globe Security Systems.

By contrast, in 1987 a six-person Colorado Springs jury awarded $\$ 2$ to Patricia James and $\$ 502$ to each of her two teenage daughters after security guards at K-Mart twisted the daughters' arms behind their backs, threw them against a wall, and strip-searched them, believing that the daughters had shoplifted. ${ }^{2}$ The plaintiffs in this case were unable to afford expert medical or psychological testimony. The jury awarded nothing in punitive damages.

Anecdotal accounts such as these serve to illustrate the possibility for uneven compensation in the civil justice system and have been used by critics to argue that jury verdicts and awards are capricious, spurious, and unpredictable. $^{3}$ However, such claims usually fail to analyze the jury decisionmaking processes that yield such varying results. This lacuna exists because very little is known about the ways in which jurors attempt to

Copyright $\odot 1989$ by Law and Contemporary Problems

- Assistant Professor of Psychology, University of Colorado, Colorado Springs.

1. Sterling v. Beckenheimer's, Inc., No. 85007033-CL29360 (Circuit Court for Baltimore City, Nov. 19, 1987), rev'd sub. nom. Globe Security Systems Co. v. Sterling, 79 Md. App. 303, 556 A.2d 731,732 (1989) (reversible error to admit expert psychiatric testimony which usurped the jury's role as determiner of witness credibility). 1987).

2. James v. K-Mart, No. 86CV2422 (Fourth Judicial District Court, Colorado Springs, Sept. 15,

3. See J. Frank, Courts on Trial 110-16 (1949). 
compensate a plaintiff for injuries that result from the defendant's actionsthe ways in which jurors attempt to make an injured plaintiff whole.4

In contrast to our knowledge of the products of decisionmaking in civil litigation, ${ }^{5}$ we know very little about the process of jury decisionmaking. And yet, claims of randomness and capriciousness seem to imply more than misdirected outcomes. Implicit in this argument is an allegation that the task of allocating damages is outside the realm of jurors' competence. ${ }^{6}$

This article will review the small body of literature on the process of determining damages in civil lawsuits, and lend an empirical foundation to the ongoing debate over the competence of the jury to make reasoned and equitable damage awards. Part II describes the freedom the jury has historically been accorded in damage award determinations. Part III details the means by which this issue has been studied, including comparisons between judges and juries, archival analyses, and interview and mock jury studies. Part IV describes the relevant findings from this research. Finally, the competence of jurors to assess damages and return reasoned verdicts is considered.

\section{II}

\section{Jurors' Freedom to Determine Damages}

One reason that the process by which jurors assess damages has largely escaped academic scrutiny is that jurors have historically been accorded vast freedom in this area. ${ }^{7}$ Judges often send jurors to deliberate with a minimum of guidance as to how their damage calculations should proceed. ${ }^{8}$ Jurors are frequently instructed that the law has provided no fixed standards by which to measure pain and suffering, for example. In short, few rules specify how this game is to be played.

The situation is further complicated by the fact that although normative issues clearly underlie decisions about compensation, "there is . . . no standard man, no reasonable man afoot in the law of damages." 9 Thus, it may be extremely difficult to determine an adequate and appropriate amount of money to compensate an injured person for feelings of pain and suffering, or for lost biological functioning, professional standing, or business opportunity. Further, identical injuries may have radically different effects on different plaintiffs: A dancer who loses a finger still has two feet; a cellist who loses a finger has lost her career. Because we lack the ability to attach price

4. Kalven, The Jury, the Law, and the Personal Injury Damage Award, 19 Онго Sт. L.J. 158, 160 (1958).

5. See, e.g., A. Chin \& M. Peterson, Deep Pockets, Empty Pockets: Who Wins in Cook County Jury Trials (1985); M. Peterson, Compensation of Injuries: Civil Jury Verdicts in Cook County (1984); M. Peterson, Punitive Damages: Preliminary Empirical Findings (1985).

6. Cf. J. Frank, supra note 3 , at 116-22.

7. Kalven, supra note 4 , at 160-64.

8. J. Guinther, The Jury in America (1988); M. Selvin \& L. Picus, The Debate over Jury Performance: Observations from a Recent Asbestos Case (1987).

9. Kalven, supra note 4 , at 160 . 
tags to given functions and talents, the translation of social wrongs into dollars and cents is problematic, at best. ${ }^{10}$

The law does provide some rudimentary ground rules for these determinations by breaking the loss into discernible components. For example, jurors in negligence cases often hear testimony concerning medical expenses, economic loss, and pain and suffering and could use these categories as an organizing framework to guide their deliberations. Nevertheless, complexity remains because jurors are often asked to make a decision on the basis of incomplete and conflicting evidence. The jury is essentially asked to guess the future:11 "How long will the pain last?"; "How fully will the plaintiff recover?"; "How much will the dollar be worth in the future?"; "How valuable will this child's life be?" Plaintiffs and defendants will have quite divergent responses to these questions.

With recent concerns over the litigation explosion ${ }^{12}$ and calls for tort reform, ${ }^{13}$ interest in jury damage awards has reappeared. Early work in this area, conducted by social scientists and legal scholars, attempted to define the jury's task in descriptive terms. ${ }^{14}$ More recently, psychologists and other social scientists have conducted a number of empirical studies on the processes of awarding compensation. ${ }^{15}$ A representative sampling of this work will be described in light of the methodologies developed to study the issue.

10. R. MacCoun, Getting Inside the Black Box: Toward a Better Understanding of Civil JURY BehaVIOR $31-34$ (1987).

11. Kalven, supra note 4.

12. See, e.g., Civiletti, Zeroing in on the Real Litigation Crisis: Irrational Justice, Needless Delays, Excessive Costs, 46 MD. L. REv. 40 (1986); Galanter, The Day After the Litigation Explosion, 46 MD. L. REv. 3 (1986); Saks, If There be a Crisis, How Shall We Know It?, 46 MD. L. Rev. 63 (1986).

13. The insurance industry has lobbied for legislative reforms to end what it calls a crisis in the civil justice system. Examples of the proposed reforms include caps or ceilings placed on the amounts jurors can award, restricted punitive damage awards, and restructured contingency fee arrangements. Daniels, The Question of Jury Competence and the Politics of Civil Justice Reform: Symbols, Rhetoric, and Agenda-Building, Law and Contemp. Probs., Autumn 1989, at 269; Daniels \& Martin, Jury Verdicts and the "Crisis" in Civil Justice, 11 Just. SYs. J. 321,323 (1986).

14. See, e.g., Broeder, The University of Chicago Jury Project, 38 NEB. L. Rev. 744 (1959); Broeder, Plaintiff's Family Status as Affecting Juror Behavior: Some Tentative Insights, 14 J. PuB. L. 131 (1965); Kalven, supra note 4.

15. See, e.g., Goodman, Greene \& Loftus, Runaway Verdicts or Reasoned Determinations: Mock Juror Strategies in Awarding Damages, 29 Jurimetrics J. 285 (1989); Hans \& Ermann, Responses to Corporate Versus Individual Wrongdoing, 13 LAW \& Hum. BEHAvior 151 (1989); Horowitz \& Bordens, The Effects of Oullier Presence, Plaintiff Population Size, and Aggregation of Plaintiffs on Simulated Civil Jury Decisions, 12 LAw \& Hum. Behavior 209 (1988); Kaplan \& Miller, Group Decision Making and Normative l'ersus Informational Influence: Effects of Type of Issue and Assigmed Decision Rule, $53 \mathrm{~J}$. Personality \& Soc. Psychology 306 (1987); Raitz, Greene, Goodman \& Loftus, Determining Damages: The Influence of Expert Testimony on Jurors ' Decision Making (in press, LAw \& HuM. BEHAv. (1990)); Sonaike. The Infuence of Jury Deliberation on Juror Perception of Trial, Credibility, and Damage Awards, 1978 B.Y.U. L. REV. 889; Wasserman \& Robinson, Extra-legal Infuences, Group Processes, and Jury Decision-making: A Psychological Perspective, 12 N.C.C.U. L.J. 96 (1980). 
III

\section{Jury Damage Awards: How They Have Been Studied}

\section{A. Comparing Juries and Judges}

The first large-scale study of jury decisionmaking in civil lawsuits was conducted by the Jury Project at the University of Chicago Law School in the 1950 's. ${ }^{16}$ These researchers evaluated the jury's decisionmaking competence in light of shadow verdicts delivered by judges in the same cases. They obtained reports of actual cases tried to the jury, the jury's liability and damage verdicts in each case, and a statement from the judge as to how he would have decided the case had he been the sole arbiter.

In personal injury cases, the judge and jury agreed on liability 79 percent of the time. ${ }^{17}$ More interesting, however, was the fact that the judges and juries disagreed considerably on damage awards. In 52 percent of the cases in which judge and jury agreed that the defendant was liable, jurors awarded more in damages; in 37 percent of cases where the defendant's liability was agreed upon, jurors awarded less; and in only 9 percent of cases did jury and judge agree on the level of damages. Overall, jury awards averaged 20 percent higher than judges' awards. ${ }^{18}$

The authors made some further observations on the issue of jury competence. In their study, judges were asked to classify each criminal case as easy or difficult to understand. In theory, any propensity toward misunderstanding by jurors should be more apparent in cases that judges rated difficult. Jury/judge disagreement would likely manifest itself in these cases. The data showed otherwise: The level of disagreement (on guilt verdicts) was nearly identical for easy and difficult cases. Assuming that these data would apply to civil cases, Kalven suggested that the intellectual incompetence of the civil jury had been vastly exaggerated. ${ }^{19}$

Data from the Chicago Jury Project have withstood the test of time and have formed the foundation for much recent debate about the competence of both criminal and civil juries. The data provide little information, however, about the intricacies of applying law to facts in order to reach a verdict. The Chicago study has little to say about the ways in which verdicts are reached and awards determined. These limitations also apply to large-scale archival analyses, a second means of assessing jury performance. However, much information about trends in jury awards can be gleaned from these large case studies.

16. See, e.g., H. Kalven \& H. Zeisel, The American Jury (1966); Broeder, The University of Chicago Jury Project, supra note 14; Kalven, supra note 4, at 159; Kalven, The Dignity of the Civil Jury, 50 VA. L. REv. 1055 (1964).

17. Kalven, supra note 16 , at 1065 . In $44 \%$ of the cases, both groups found for the plaintiff and in $35 \%$ of the cases both found for the defendant. Id.

18. Id.

19. Id. at 1066-68. 


\section{B. Archival Analyses}

Archival studies of jury decisionmaking involve statistical analyses of large data sets, often culled from jury reporting services. The virtue of archival studies is that they allow researchers to evaluate the impact of different factors on a particular variable, such as the size of the compensatory damage award.

One archival study examined over 9000 civil cases tried in Cook County, Illinois, and over 5000 cases tried in San Francisco between 1960 and 1979.20 These researchers were interested in how factors such as (1) the attributes of the defendant (an individual versus a corporation), (2) the plaintiff's degree of negligence, and (3) the delay between the time of injury and trial affected damage awards. Their data showed that juries returned larger awards against corporate defendants despite their instructions that the defendant's resources should not influence the size of an award; ${ }^{21}$ that even in states without comparative negligence standards, jurors discounted the awards of partially negligent plaintiffs; 22 and that juries provided some prejudgment interest to compensate the plaintiff for the delay between injury and trial. ${ }^{23}$

An archival analysis can reveal that these factors affect the awards, but it cannot explain why they affect the awards. Thus, the researchers could determine that jurors do indeed discount damages in accordance with the plaintiff's negligence, but were unable to determine why this was so or how jurors reached this conclusion. For example, did jurors agree on a sum to compensate the plaintiff for her injuries and then reduce the amount in accordance with their assessment of her comparative negligence? Or did they begin their deliberations with a discussion of her role in the accident? Did they agree on an exact percentage figure to represent her share of the blame? Did their beliefs about her negligence affect their determination of punitive damages? Because archival analyses cannot answer these detailed questions, they are of limited usefulness when the process of decisionmaking is of interest, and questions such as "Why?" and "In what way?" are paramount.

\section{Interviewing Jurors}

Recently, social scientists and lawyers have begun to interview jurors subsequent to their jury service and have been able to probe the processes of decisionmaking. These studies have often been conducted after highly publicized, complex, and/or lengthy trials. ${ }^{24}$

20. Hammitt, Carroll \& Relles, Tort Standards and Jury Decisions, $14 \mathrm{~J}$. Legal. Stud. 751,752 (1985). The study also analyzed approximately 200 verdicts taken from a sample of automobile insurance claims closed with some payment to the insured during a two-week period in 1977 . Id. at 753.

21. Id. at 754 .

22. Id. at 756-57.

23. Id. at 758-61.

24. See, e.g., A. Austin, Complex litigation Confronts the Jury System: A Case Study (1984); T. Petzinger, Oil and Honor: The Texaco-Pennzoll Wars 399-408, 483-84 (1987); M. Selvin \& L. Picus, supra note 8. See generally Note, Public Disclosures of Jury Deliberations, 96 HaRv. L. REv. 886 (1983) (discussing potentially adverse effects of exposing the deliberative process to public criticism). 
Austin $^{25}$ interviewed two sets of jurors in City of Cleveland v. Cleveland Electric Illuminating Co., ${ }^{26}$ in which the city sued the rival of its municipal utility for violations of the Sherman Antitrust Act. ${ }^{27}$ When questioned about calculations of damages, jurors in the first group related that they never discussed damages in their deliberations, and did not retain details about the damages testimony. Austin discerned from jurors' responses that they lacked interest in issues related to damages because they did not expect to be given the responsibility of calculating damages, despite the fact that they heard extensive testimony on this topic. They assumed that their only function was to determine the defendant's liability. ${ }^{28}$

Jurors in the second group generally agreed that it would have been extremely difficult to calculate damages. ${ }^{29}$ Despite judicial instructions on damages that mentioned possible future losses, the impact of inflation, and a discount formula, one of the alternate jurors assumed that the judge, rather than the jury, would calculate damages.

Selvin and Picus ${ }^{30}$ interviewed the jurors who decided an asbestos products liability case in Texas in 1984. ${ }^{31}$ From those interviews emerged the picture of a well-intentioned jury that nonetheless awarded compensation for expenses they were not to consider and that evaluated extra-legal factors when determining punitive damages.

To compensate each of the four plaintiffs who had contracted some form of asbestosis, the jury calculated and then summed past and future lost earnings, medical expenses, and figures to compensate for pain and suffering. These calculations were based on information about employment histories, life expectancies, and medical expenses. Jurors used a process described as "guesstimation" 32 to determine an amount for pain and suffering. Finally, to calculate punitive damages, they evaluated each defendant's financial resources and decided to assess $\$ 1$ million against four of the ten defendants.

The largest damage award ever recorded came in 1985 from the twelveperson jury that decided that Texaco interfered with Pennzoil's attempt to acquire Getty Oil Company. ${ }^{33}$ Two jurors-the foreman and another highly

25. A. Austin, supra note 24.

26. 440 F. Supp. 193 (N.D. Ohio 1976), aff'd, 573 F.2d 1310 (6th Cir. 1977)

27. The first trial ended in a mistrial in November 1980 when the jury could not resolve a 5-1 deadlock in favor of the plaintiff. The second trial ended in October 1981 with a verdict for the defense. A. Austin, supra note 24, at 21.

28. Id. at 34-35.

29. Some jurors commented: "I think I would have floundered on that one"; "I don't know how you come up with the amounts-I really don't know." Id. at 52.

30. Supra note 8

31. Newman v. Johns-Manville Sales Corp., No. M-79-124-CA (E.D. Tex. Oct. 24, 1984). The jury found each of ten defendants liable for the four plaintiffs' injuries and awarded a total of $\$ 3.9$ million in compensatory damages and $\$ 4$ million in punitive damages against four of the ten defendants. M. Selvin \& L. Picus, supra note 8 , at v-vi.

32. M. Selvin \& L. Picus, supra note 8, at 38.

33. The jury awarded Pennzoil $\$ 7.53$ billion in compensatory damages and $\$ 3$ billion in punitive damages; with prejudgment interest, the award totaled $\$ 11.2$ billion. A Texas court of appeals upheld the compensatory damages but reduced the punitive damages to $\$ 1$ billion, calling that 
influential jury member-granted extensive interviews after the trial. ${ }^{34}$ Although jurors were concerned during deliberations about the potential size of their compensatory damage award, they apparently felt they had little choice. ${ }^{35}$ Texaco decided not to present any damages testimony. Thus, when the jury considered the instructions to "not consider or discuss anything that is not represented by the evidence in this case," 36 they felt they had no role in fabricating a case for Texaco. The vote was 10-2.37

Punitive damages proved to be the most contentious issue discussed by the jury. Six jurors wanted to assess punitive damages at $\$ 7.53$ billion, and two jurors held out at zero. The foreman persuaded one group to reduce its assessment if another group would increase theirs. Finally, an influential juror realized that the group needed a rationale-a formula of some kind-to agree on punitive damages. The $\$ 3$ billion figure eventually agreed upon represented $\$ 1$ billion against Texaco for each of the indemnities the jury had awarded. That number was apparently a nearly perfect compromise between the high and low figures that jurors had been arguing over. Thus, although the damages in this case were arguably forty times larger than the largest award in any prior case, descriptions of the deliberation process suggest that the jury attempted to base its decision on the evidence it heard and on a formulaic calculation of punitive damages. ${ }^{38}$

Although interview data can illuminate the process of decisionmaking in actual cases, they have certain shortcomings. Jurors may not accurately remember or relate their experiences. Some jurors may not consent to be interviewed. Generalization beyond the particular case is limited. ${ }^{39}$ Thus, researchers have increasingly begun to study jury decisionmaking by staging a trial for mock jurors and recording their deliberations either on audio or videotape.

\section{Mock Jury Studies}

Mock jury studies permit researchers to manipulate those features of the trial they wish to evaluate (for example, the identity of the defendant, or the amount of money requested by the plaintiff's attorney), and present the same trial via videotape to multiple juries. Thus, researchers are able to evaluate how a large number of mock jurors-often college students but, increasingly, jurors who have recently completed jury duty-react to the facts and legal

amount adequate under the circumstances. Texaco, Inc. v. Pennzoil Co., 729 S.W.2d 768, 866 (Tex. C. App. 1987), cert. dismissed, 485 U.S. 994 (1988).

34. T. Petzinger, supra note 24 , at 483.

35. One juror commented: "The law entided Pennzoil to all the damages necessary to make itself whole, and Pennzoil had documented the number backward and forward. Pennzoil's damages expert-an impressive witness, an unpaid witness!-had called the number 'conservative.' "Id. at 404.

36. Id.

37. Id.

38. See id. at 404-08.

39. See generally R. MACCoun, supra note 10 , at 8-9. 
issues of the case. More importantly, the procedure allows for recording and subsequent analysis of the mock jurors' deliberations.

This methodology has been used to examine, among other things, the impact on damage awards of the ad damnum (the amount requested by the plaintiff $;{ }^{40}$ the size of the plaintiff population;'41 various kinds of verdict forms; ${ }^{42}$ the identity of the defendant; ${ }^{43}$ the defendant's liability insurance; ${ }^{44}$ the means by which the plaintiff was injured; 45 and the impact of expert economic testimony. ${ }^{46}$ The results of many of these studies will be described in the sections that follow. In general, mock jury studies may be limited by the fact that jurors know that the consequences of their decisions are not binding and that their deliberations are being recorded or observed. ${ }^{47}$ Subjects may select their words and arguments more carefully than they might in a real trial and may be less likely to invest their time and mental energy in the deliberation process. Still, mock jury studies allow for generalization beyond a given group of jurors and can provide systematic evidence to complement the anecdotal or statistical data collected by other means. Provided that researchers exercise caution in generalizing from their studies to real-world situations, mock jury research can provide useful clues about ho'w jurors process information and make decisions. ${ }^{48}$

\section{IV \\ Jury Damage Awards: What We Have Learned}

A. Jurors May Fuse Liability and Compensatory Damage Issues

One view of the purpose for compensatory damages is that they are intended to return the plaintiff to preinjury levels of functioning-to right the wrongs inflicted by the defendant. ${ }^{49}$ In theory, these awards should reflect the plaintiff's circumstances and be independent of the defendant's moral culpability. Stated otherwise, if the jury believes that a preponderance of the evidence, however narrow, favors the plaintiff, they are to compensate for all damages proved and not vary the award as a function of the fault of the

40. J. Zuehl, The Ad Damnum, Jury Instructions, and Personal Injury Damage Awards (Aug. 4, 1982) (unpublished manuscript).

41. Horowitz \& Bordens, supra note 15.

42. E. Wiggins, Procedural Innovations to Enhance Juror Comprehension in Complex Litigation (1988) (unpublished manuscript).

43. Hans \& Ermann, supra note 15; Wasserman \& Robinson, supra note 15.

44. Broeder, The University of Chicago Jury Project, supra note 14, at 753-55.

45. Goodman, Greene \& Loftus, supra note 15.

46. Raitz, Greene, Goodman \& Loftus, supra note 15.

47. See generally Bray \& Kerr, Use of the Simulation Method in the Study of Jury Behavior, 3 LAw \& Hum. Benav. 107 (1979); Vidmar, The Other Issues in Jury Simulation Research, 3 LAW \& HuM. BeHAV. 95 (1979); Weiten \& Diamond, A Critical Review of the Juny Simulation Paradigm, 3 Law \& Hum. Benav. 71 (1979).

48. R. MacCoun, supra note 10 .

49. Kalven, supra note 4 , at 160 . 
defendant. ${ }^{50}$ There is evidence, however, that liability issues may intrude in discussions of compensatory damages. ${ }^{51}$ Thus, damage awards may do more than compensate the plaintiff; they may also reflect the jury's sentiments about the defendant's culpability.

Broeder suggests that damage awards will generally vary with the strength of the evidence against the defendant, rather than as a function of the plaintiff's loss only. ${ }^{52}$ Broeder had thirty mock juries view a negligence case in which the plaintiff was injured in a collision with the defendant's automobile. Broeder varied the liability of the defendant so that half the juries viewed a case in which liability was very clear. For the other jurors, liability was less clear. Injuries to the plaintiff remained constant for both groups. The mean award in the first group was $\$ 41,000$ and in the second, $\$ 34,000$. In this study, the weaker the proof on liability, the lower the award. ${ }^{53}$

More recently, Hans and Ermann used a mock jury setting to determine whether jurors reacted differently to corporate and individual defendants in a negligence case. ${ }^{54}$ These researchers found that even when injuries to the plaintiff were held constant and the actions of the defendants (corporate versus individual) were identical, the corporation was more likely to be held liable, and was judged to be more reckless and morally wrong in its behavior. In line with the fusion of liability and damages, jurors awarded the plaintiff more when the defendant was a corporation.

These studies suggest that sentiments about liability can linger beyond discussion of this issue and can affect jurors' subsequent deliberations about compensatory damages. However, another possibility must be considered. Lloyd-Bostock suggests that the process may operate in the reverse direction: that jurors' desires to compensate a needy plaintiff may influence their willingness to find the defendant liable. ${ }^{55}$ If factfinders decide that the defendant can provide compensation, they may hold that defendant liable, regardless of his or her actual culpability. Whether the influence operates in a forward (that is, liability judgments influence damage awards) or backward direction (that is, sentiments about damages affect liability judgments), the effect is the same: The calculation of compensatory damages is not

50. Id. However, in states that still hold to the contributory negligence doctrine, the plaintiff will lose the case if at fault to any degree. In these instances, the plaintiff's negligence-however minimal-bars recovery. Id. at 168 .

51. "If we imagine for a moment a series of cases in which the facts as to damages remain identical but the facts as to liability range over the full and rich possibilities of negligence, the legal view is that the award should be constant throughout the series. The jury's view is that these may be significantly different cases." Kalven, supra note 4, at 165-66.

52. Broeder, The University of Chicago Jury Project, supra note 14, at 753-54.

53. Id. at 754 .

54. Hans \& Ermann, supra note 15.

55. Lloyd-Bostock, Attributions of Cause and Responsibility as Social Phenomenon, in Attribution Theory and Research: Conceptual, Developmental and Social Dimensions 261 (J. Jaspars, F. Fincham \& M. Hewstone eds. 1983). 
independent of other considerations. Rather, the defendant's culpability is factored into the equation.

\section{B. Procedures Used to Calculate Damage Awards}

1. The Simplest Case: Anchoring on a Suggested Figure. The ad damnum is the sum requested by the plaintiff's attorney to compensate the plaintiff adequately. Broeder suggests that the ad damnum does "yeoman service as a kind of damage jumping-off place for the jurors." 56 He interviewed jurors in eleven personal injury cases to determine whether the size of the ad damnum influenced their damage awards. In six of seven cases in which the plaintiff prevailed, damages were determined to some degree with reference to the ad damnum. Broeder describes the case in which the ad damnum had its greatest impact: The plaintiff was seeking $\$ 2400$ for loss of the use of his tractor, among other things. Jurors began their deliberations with a lengthy discussion of the $\$ 2400$ figure and eventually agreed to award half that amount. One juror explained that "lawyers always ask for about twice what they really expect." 57

This issue has also been studied in a mock jury setting. Zuehl had sixtynine juries watch a personal injury case in which the ad damnum was systematically varied while the facts of the case were held constant. Different groups of jurors were given suggested amounts of $\$ 10,000, \$ 75,000$, $\$ 150,000$, or "substantial compensation." 58 Data from the study suggest that jurors used the ad damnum either as an anchor or as an upper boundary for their awards because when an exact dollar figure was requested, half the awards matched that figure. Further, jurors who did not match the suggested amount tended to adjust downward from the ad damnum, ${ }^{59}$ and compliance with the figure decreased as the requested amount increased. The average awards in the exact-request conditions were $\$ 18,000, \$ 62,800$, and $\$ 101,400$.

Monetary awards suggested by expert economic witnesses in cases involving personal injury, antitrust violation, trademark infringement, or employment discrimination, for example, may also serve to anchor jurors' damage awards. In fact, the expert's figures may have considerably more impact than the ad damnum because of the perceived credibility and expertise of the witness. ${ }^{60}$

56. Broeder, The University of Chicago Jury Project, supra note 14, at 756.

57. Id. at 757 .

58. Zuehl, supra note 40 . This simulation was based on an actual case in which the jury awarded $\$ 65,000$. Thus, Zuehl anticipated that jurors who received the $\$ 75,000$ request would be most likely to endorse the ad damnum.

59. Only three juries exceeded the ad damnum and all three had received requests for only $\$ 10,000 . I d$.

60. See, e.g., State v. Saldana, 324 N.W.2d 227, 230 (Minn. 1982), in which a court reversed a criminal sexual conduct conviction partially because an improper use of expert testimony created a misleading "aura of special reliability and trustworthiness," and United States v. Fosher, 590 F.2d 381,383 (1st Cir. 1979), in which courts have expressed concern that jurors will be overly impressed by an expert witness and will place undue weight on his or her testimony. See also Eagly \& Chaiken, Cognitive Theories of Persuasion, in 17 Advances in Experimental Social Psychology 267 (L. Berkowitz ed. 1984). 
This issue has been examined in a study by Raitz, Greene, Goodman, and Loftus. ${ }^{61}$ They presented excerpts from transcripts of a wrongful termination case to mock jurors and varied the presence of expert economic testimony. One-third of the jurors heard no expert testimony. Thus, no figure was suggested by the plaintiff as adequate compensation for past and future lost wages. One-third heard testimony from an economist for the plaintiff who suggested a $\$ 719,354$ compensatory award. One-third were exposed to two experts: an expert for the plaintiff who suggested $\$ 719,354$ and an opposing defense expert economist whose figures were based on slightly different assumptions about salary increases, interest rates, and inflation and who suggested $\$ 321,000$.

Data from this study show that jurors relied on the experts' suggestions. The median awards in these three conditions were $\$ 366,000, \$ 700,000$, and $\$ 630,000$, respectively. Further, when jurors were asked to describe how they arrived at their decisions and their responses were analyzed, researchers determined that 55 percent of jurors exposed to the plaintiff's expert mentioned something about endorsing the expert's figure, and 66 percent of jurors in the two-expert condition mentioned endorsing one of the experts' figures. Thus, jurors often seem to anchor onto the damage awards suggested by expert witnesses when faced with the difficult task of evaluating factors such as worklife expectancy, the possibility for promotions, and exponential salary increases. Under such conditions of uncertainty, the ad damnum and the expert's request represent foundations from which jurors can begin their deliberations. As their deliberations proceed, jurors often return to and endorse these suggestions.

2. The Gestalt Approach: Searching for a Single Sum. Kalven suggests that "a major characteristic of the jury's approach to damages . . . is that it does not much concern itself with the damage components as an accountant might but searches rather for a single sum that is felt to be appropriate."62 According to Kalven, this holistic approach results because jurors are often presented with a damages instruction that contains a long, complex sentence or two but that does not suggest that jurors first derive a series of component sums. Therefore, the damages awarded may reflect the jury's general sentiments about the case and the parties involved, rather than an itemized accounting of the plaintiff's losses.

Another possibility is that jurors might determine a single sum that they believe represents adequate compensation and then work backwards to apportion it into several categories. ${ }^{63}$ Jurors may be more likely to use this strategy if they are given a special verdict form requiring separate assessments of loss to the plaintiff rather than a general verdict form. Although this

61. Supra note 15.

62. Kalven, supra note 4, at 161 .

63. Id. at 162 . 
method appears to give a result that is the sum of different damage components, it is, in fact, premised on a single-sum assessment.

Are there data to support the contention that jurors search for a single sum to compensate the plaintiff? In a word, no. Kalven suggests that his assumption is based on the Chicago Jury Project findings, but he fails to document instances of this gestalt-like reasoning in jurors. In fact, recent interview and mock jury studies show something quite different than this single-sum approach. This research suggests that jurors do assess various components in a case (for example, medical expenses, economic losses, pain and suffering) and add the component sums to arrive at a compensatory award. ${ }^{64}$

3. Adding Component Sums to Determine an Award. Jurors interviewed after a toxic tort case described how they evaluated each component of each plaintiff's complaint and computed a single-sum award only after making these componential calculations. ${ }^{65}$ Thus, for each of the four plaintiffs, jurors calculated and then summed past and future lost earnings, past medical expenses (even though the judge specifically instructed them not to consider these), future medical expenses, and the cost of past and future pain and suffering. Often, they determined amounts that they then applied to all of the four plaintiffs. For example, they estimated all plaintiffs' past medical expenses at $\$ 12,000$ per year and future medical expenses at $\$ 15,000$ per year. The jury determined that each plaintiff should receive $\$ 6,000$ per year as compensation for past and future pain and suffering. ${ }^{66}$ The findings suggest that although these jurors did not deliver completely individualized judgments, they did evaluate each plaintiff's case on its merits; more importantly, they broke each complaint into its component parts, computed an award for each component, and then summed the results.

Results of mock jury studies also support the hypothesis that juries reach damage awards by adding component sums. Goodman, Greene, and Loftus presented vignettes to jurors that described a wrongful death case involving either medical malpractice, products liability, or negligence. ${ }^{67}$ Jurors were informed that liability had already been decided in favor of the plaintiff and that their task was to award an appropriate amount in damages. Of particular interest were the strategies jurors used to determine monetary damages. Jurors wrote detailed accounts of the reasons for their awards and described the process used to decide upon that amount. These responses were analyzed for content and coded into one of five categories: (1) picked a fair and reasonable amount without computation; (2) multiplied the plaintiff's expected worklife by annual salary; (3) performed some multiplication and

64. See, e.g., M. Selvin \& L. Picus, supra note 8, at 55.

65. Id.

66. However, they reduced their computed award for one plaintiff when it became apparent that their formula would result in a higher award for him-a younger, but less seriously ill worker-than for the most seriously injured plaintiff. Id.

67. Goodman, Greene \& Loftus, supra note 15, at 292-93. 
then adjusted the award by increasing the total; (4) performed some multiplication and then adjusted the award by decreasing the total; (5) performed some computation ahd also included some recognition of an exponential growth factor (for example, inflation, salary raises, and promotions).

If jurors used a single-sum approach, their responses would likely be coded as "picked a fair number without apparent calculation." In fact, only approximately 27 percent of responses fell into this category, suggesting that most jurors utilized a somewhat more complicated technique. ${ }^{68}$ Moreover, in actual cases where jurors are given considerably more information to form the basis for their award, even fewer jurors would be likely to adopt this strategy.

Goodman, Greene, and Loftus have other data to suggest that mock jurors weigh component factors when determining an award. Subjects reviewed a list of seventeen factors (for example, the decedent's age, loss of companionship to decedent's spouse, impact of inflation) that might have influenced their decisions and were asked to indicate which of these factors they considered, even fleetingly. Approximately 80 percent of jurors said they considered the decedent's age; 90 percent listed the decedent's salary at the time of the accident; and approximately 60 percent said they considered that person's potential worklife. Other factors were mentioned less frequently: 58 percent listed emotional loss to the decedent's spouse; 26 percent said they considered the impact of inflation, and 17 percent said they considered that the plaintiff must pay attorney's fees incurred during the lawsuit. ${ }^{69}$ Although some jurors may have responded after the fact with what they believed were appropriate answers, these sizeable percentages indicate that mock jurors seem to take a variety of factors into account when deciding on a compensatory award.

The result of a detailed, componential approach-as compared to a singlesum assessment-would likely be an increase, rather than a decrease, in the damage award. ${ }^{70}$ Use of a special verdict form may force jurors to weigh component items more explicitly because it requires them to consider factors they might have otherwise overlooked. The result would likely be larger compensatory awards to the plaintiff. ${ }^{71}$

Recent research by Wiggins supports this assumption. ${ }^{72}$ She evaluated decisionmaking as a function of jury verdict forms by asking jurors to view a defamation case and deliberate about damages. Jurors were given either a general verdict form that asked them simply to find for the plaintiff or the defendant and award the appropriate damages, or a special verdict form that

68. Id. at 298.

69. Id. at 301-04.

70. "If one seriously assesses the components in a case of any magnitude, they are likely to add up to a surprisingly large figure. I take it this is one reason why the plaintiff bar sometimes expresses a preference for the accountant type juror in a case where damages are substantial and well documented." Kalven, supra note 4, at 161-62.

71. Id. at 162 .

72. Wiggins, supra note 42. 
required them to answer several questions about the case. ${ }^{73}$ Wiggins found no differences in the total damages (compensatory plus punitive damages) awarded as a function of the verdict forms, but did find differences in how the awards were allocated: The percentage of the award allocated to compensatory damages was larger for jurors with special verdict forms than for jurors with general verdict forms. ${ }^{74}$ Apparently, explicit attention to issues contended in the case causes jurors to increase the amount of compensation they believe is owed the plaintiff, but does not cause them to change what they believe is an appropriate overall sum.

4. The Effects of Deliberation. To what extent are individual jurors' preferences prior to deliberation predictive of the group award on damages? By what process do jurors reach an agreement on an award during deliberations? How does the decision rule (that is, unanimity versus majority) affect the process of compromise? Data on these issues are rudimentary and somewhat confusing.

One possibility is that the damage award is simply the mean of jurors' individual responses. Judge Frank has written that "[a]gain and again it has been disclosed that ... . [e]ach juror . . . writes down the amount he wants to award, the total is added and the average is taken as a verdict." 75

Certain data support this position. In posttrial interviews with jurors in thirty-eight federal civil trials in Philadelphia, Guinther determined that in 40 percent of the cases where jurors disagreed greatly on the amount to award in damages, they averaged the suggested amounts to reach a result. ${ }^{76}$ Another researcher noted this phenomenon in mock jury studies, but observed that it had occurred only as a last resort, after lengthy discussion failed to produce an agreement. ${ }^{77}$

Kalven suggests that jury awards are frequently close to the predeliberation averages of the group members. ${ }^{78}$ His data also indicate that jurors agree to this form of compromise only after they have made serious attempts to bridge their differences by alternative means. In other words, the jury does not simply calculate the mean of twelve individual awards and record that figure as a group verdict. The averaging method is used only when other attempts at compromise have failed. Of course, this averaging rule might accurately describe the final award even though the jury never

73. The questions included: "Did the plaintiff prove by a preponderance of the evidence that the defendant made a defamatory statement about her?"; "Did the plaintiff prove by a preponderance of the evidence that the defamatory statement injured her?"; "Did the defendant prove by a preponderance of evidence that the defamatory statement was true?". Id.

74. For jurors with a special verdict form, $73 \%$ of the award was allocated to compensatory damages; for jurors with a general verdict form, only $54 \%$ went to compensatory damages. Id.

75. J. FRANK, supra note 3, at 114 .

76. J. Guinther, supra note 8 , at 97 .

77. Id.

78. Kalven, supra note 4 , at 177 . 
explicitly calculated an average. ${ }^{79}$ Further research is needed to determine how explicit these compromises actually are.

$A$ variant on the averaging model involves the calculation, either explicit or otherwise, of a median, rather than mean award. 80 A median award accounts for all jurors' individual preferences, whereas a mean award may be skewed by one or two extreme values. Data from Sonaike's mock jury study suggest that the median of individual awards is a better measure of the group award than is the mean. ${ }^{81}$ In this study, mock jurors watched videotapes of automobile negligence cases, completed predeliberation questionnaires, and provided a group verdict and damage award. Sonaike found that the group awards tended to reflect the trend of predeliberation awards dominant within each jury, thus supporting Kalven's notion about compromise. Sonaike concluded, however, that the median, rather than the mean, was a better predictor of the ultimate group award.

A slightly more complex possibility is that jurors' individual award preferences do not carry equal weight during deliberations but instead are influenced by the juror's prestige, persuasiveness, or involvement in the deliberation. ${ }^{82}$ More persuasive jurors will have more impact on the final determination, and the extent of any juror's impact will be a function of his or her social characteristics. This method of resolution-a weighted average model-might be more likely to occur under unanimity than majority decision rules because every juror's sentiments must be addressed in the former case and thus individual strengths and weaknesses will manifest themselves. Under a majority decision rule, the minority faction can essentially be ignored. Majority and unanimity decision rules are discussed in some detail below.

Studies have developed conflicting data on the effects of deliberation on damage awards. As previously noted, Kalven ${ }^{83}$ and Sonaike ${ }^{84}$ argue that group awards tend to reflect individual jurors' predeliberation sentiments. Several studies have found otherwise. Zuehl ${ }^{85}$ reported that the mean jury award exceeded the mean predeliberation juror recommendations in all four ad damnum conditions of his study. Similarly, Wasserman and Robinson ${ }^{86}$ found that postdeliberation jury awards were generally larger than predeliberation individual awards. Finally, Kaplan and Miller ${ }^{87}$ had jurors read a products liability case and give both prediscussion individual awards and postdiscussion group awards for both compensatory and punitive

79. R. MacCoun, supra note 10 , at 33.

80. The median refers to that award in a distribution of awards above which and below which one-half of the awards fall. The mean refers to the arithmetic average of all awards calculated by summing all awards and dividing that amount by the total number of awards.

81. Sonaike, supra note 15, at 902-03.

82. R. MaCCoun, supra note 10 , at 33 .

83. Kalven, supra note 4 , at 177.

84. Sonaike, supra note 15, at 904.

85. Zuehl, supra note 40.

86. Wasserman \& Robinson, supra note 15, at 147-48.

87. Kaplan \& Miller, supra note 15, at 308-09. 
damages. They found a substantial increase in the amounts of postdeliberation awards for punitive damages only; group awards for compensatory damages did not differ from individual, prediscussion amounts. These findings suggest that the situation is more complicated than previously believed: For certain decisions, such as compensation, group awards may reflect individual awards, while for other decisions, such as punishment, this relationship may not operate.

Kaplan and Miller suggest that these findings can be explained in part by the kinds of information that jurors shared as they discussed these two issues. Jurors' discussions of compensatory damages included references to trial testimony and inferences drawn from the evidence, whereas discussions of punishment involved value statements and conformity pressure. The researchers further suggest that the particular decision rule used in the case may have exerted some influence on its outcome. ${ }^{88}$

Evidence for the significance of the decision rule comes from data collected by Judge Forer and described by Guinther. ${ }^{89}$ In determining liability, unanimous-verdict juries who deliberated in Judge Forer's courtroom were more likely than majority-verdict juries to find for the plaintiff. However, according to Judge Forer, when the jury erred on the amount of the award, unanimous-verdict juries' awards often were too low, while majority juries erred on the high side.

By means of posttrial interviews, Guinther ${ }^{90}$ was able to evaluate more systematically the role of the decision rule in contributing to these disparate awards. According to Guinther, three scenarios can develop when unanimity is required. First, in the course of deliberation, all jurors may agree on a verdict for the plaintiff and then proceed to discuss the award by evaluating the evidence relevant to damages; second, there may be no agreement on liability but the majority favors the plaintiff; and third, jurors may not agree on liability, but the majority favors the defense. In the second and third scenarios, the damages figure can become the barter that eventually allows the majority to accommodate the views of the minority. So, for example, when the proplaintiff faction is in the majority, it may obtain the concessions from the defense minority necessary to allow the plaintiff to prevail on the issue of liability by lowering the amount it wishes to award in damages. When the opposite situation arises, the prodefense forces may eventually allow a plaintiff's verdict, but only if the plaintiff-minority agrees to a reduced damages award. In both cases, the result is that the plaintiff wins, but receives a lower award.

In juries where only majority agreement is required, these compromises come into play only when the vote is relatively evenly split. Otherwise, the majority forces need pay little heed to the minority position. Thus, when the majority favors the plaintiff, they need not lower the amount they want to

88. Id.

89. J. Guinther, supra note 8.

90. Id. at 96 . 
award in order to extract concessions from the defense-minority. As a result, the plaintiff receives more money.

In 54 percent of the cases he studied in which a unanimous verdict was required and the plaintiff prevailed, the data suggest the majority agreed to reduce their award in order to obtain agreement from the defense-minority. In jurisdictions that used a five/six rule, ${ }^{91}$ such reduction occurred only 33 percent of the time. ${ }^{92}$

The data on the effects of deliberation suggest that jurors' discussions about damages can be complex and motivated by subtle attempts at persuasion and compromise. They further suggest that jurors do not routinely average their awards and compromise on the mean. Rather, jurors attempt other forms of conciliation, including subtle compromise on damages in order to reach consensus on liability. Only when these methods fail do jurors revert to the simpler averaging technique. The data also suggest that different processes may operate and different information may be exchanged when jurors discuss compensatory as opposed to punitive damages.

\section{The Impact of "Silent Factors": Attorneys' Fees, Taxation, Insurance, and Prejudgment Interest}

Jury instructions are often silent on the topics of attorneys' fees, the taxability of damage awards, plaintiffs' and defendants' insurance, and prejudgment interest used to compensate plaintiffs for the delay prior to the receipt of an award. Jurors are typically given no information about whether they should or should not consider these factors; however, evidence is accumulating that jurors do discuss these issues during their deliberations. ${ }^{93}$

1. Attorneys' Fees. In theory, jurors are not to award fees for counsel as part of the plaintiff's compensation; ${ }^{94}$ however, jurors often discuss fees in their deliberation and see no impropriety in doing so. ${ }^{95}$ One-quarter of the mock jurors questioned by Goodman, Greene, Loftus, and Raitz said that they contemporaneously considered the payment of attorneys' fees as they decided on a compensatory award in a wrongful termination case. ${ }^{96}$ These jurors would likely raise the issue during deliberations. Additionally, jurors are

91. That is, five of six jurors must agree.

92. J. Guinther, supra note 8 , at 82 .

93. See, e.g., J. Guinther, supra note 8, at 97; M. Selvin \& L. Picus, supra note 8, at 55; Broeder, The University of Chicago Jury Project, supra note 14, at 751; Erlanger, Jury Research in America: Its Past and Future, 4 Law \& Soc'y REv. 345, 350 (1970); Hammitt, Carroll \& Relles, supra note 20, at 755.

94. This issue has been contended at the appellate level. In Renaurt Lumber Yards, Inc. v. Levine, 49 So. 2 d 97 (Fla. 1950), the court decided that a $\$ 75,000$ damages award was excessive, estimated that $\$ 30,000$ of the award covered pain and suffering, and ordered a remittitur. In dissent, Justice Hobson argued "although there is no legal basis for the inclusion of an attorney's fee in the judgment it is a matter of common knowledge that in personal injury actions lawyers do not customarily perform services gratuitously. As a practical proposition it is indeed probable that after paying for the services of his attorney appellee would have little, if any, of the $\$ 30,000$ left." Id. at 102 (Hobson, J., dissenting).

95. Kalven, supra note 16 , at 1069.

96. Raitz, Greene, Goodman \& Loftus, supra note 15. 
relatively well informed about the usual one-third contingency arrangement. ${ }^{97}$

According to Kalven, the importance of this issue varies inversely with the difficulty of assessing damages. ${ }^{98}$ His data suggest that in cases where damages are easy to define and compensation levels are uncontroverted, the jury is not apt to discuss attorneys' fees. In cases where jurors disagree about an appropriate level of compensation, discussion of attorneys' fees is more common. Kalven suggests that discussion of fees acts as a device to facilitate agreement during deliberation. Often, the issue is raised in an attempt to persuade a reluctant juror to raise the amount he or she is willing to award. ${ }^{99}$

Do jurors routinely add to the award to cover the payment of attorneys' fees? Kalven would argue that they do not. ${ }^{100}$ Some recent empirical data suggest that they do. ${ }^{101}$ Jurors interviewed in an asbestos case indicated that they added approximately 40 percent to the computed award to cover attorneys' fees. ${ }^{102}$ Thus, although the jury was instructed to consider "the following elements of damage, and none other," 103 and the topic of attorneys' fees was never mentioned in court, jurors in this case apparently did not hesitate to increase their award to reflect payment of counsel's fees. ${ }^{104}$

It is difficult to determine whether these anecdotal reports are representative of most juries' experiences on this issue. Jurors questioned about their discussions of attorneys' fees may hesitate to divulge such information, believing that by discussing this issue they may have acted against the court's orders. However, given the evidence from several studies, jurors apparently often discuss contingency fee structures, and they occasionally adjust their damage awards with this factor in mind.

2. The Plaintiff's Insurance. Guinther assessed the role of insurance in jurors' decisions in interviews with jurors subsequent to federal civil trials. When jurors were asked if they personally considered that the plaintiff might

97. Eighty-four percent of jurors questioned by Guinther said that a plaintiff typically pays his lawyer a percentage of the total verdict. J. Guinther, supra note 8 , at $33 \mathrm{l}$.

98. Kalven, supra note 16 , at 1069 .

99. In one of the experimental jury deliberations there was a sharp split in the jury over the damages. The majority faction favored $\$ 35,000$, and the minority $\$ 25,000$. After considerable discussion the impasse seemed firm. Finally, one of the majority raised the fee issue for the first time and reminded the holdouts that the plaintiff would have to pay his lawyer. The holdouts agreed that this was a point they had not previously considered and yielded rather rapidly. An overly logical member of the majority then raised the point that in reaching their figure of $\$ 35,000$ they had not considered fees either. He was summarily silenced by the other majority jurors, and a verdict of $\$ 35,000$ was unanimously agreed upon. Id. at 1070 .

100. Id. at 1069 .

101. M. Selvin \& L. Picus, supra note 8, at 55.

102. One juror remarked:

He just got $\$ 572,000$ and had to give the lawyer half of it, then he wouldn't have the money that maybe he needs for his medical expenses for the rest of the time he's going to be alive, and I didn't think ... that he should have to pay out of his pocket for hiring a lawyer to take the company to court.

Id. at 38-39.

103. Id. at 74 .

104. Id. 
have either medical insurance or workmen's compensation to cover part or all of the injury expenses, 29 percent acknowledged that they had. However, less than 10 percent said that this belief had any impact on their award and less than 2 percent said that it had substantially affected their decision. ${ }^{105}$

In contrast, when asked whether the jury as $a$ whole acted on that belief, 13 percent of jurors said their jury lowered the award because they believed the plaintiff had part or all of his or her injuries covered by other sources. ${ }^{106}$ Because the judge's charge did not mention this consideration, jurors may have been reluctant to admit that they individually considered the plaintiff's insurance. Still, only occasionally did they reduce their awards because of their beliefs about the plaintiff's insurance.

3. The Defendant's Liability Insurance. The possibility that the defendant is insured is also considered by the jury during deliberations about damages. ${ }^{107}$ In general, if jurors believe a defendant is insured, they will often return a higher award. ${ }^{108}$ Fifty-four percent of jurors questioned by Guinther said they considered that the defendant carried insurance. ${ }^{109}$ However, like attorneys' fees, this factor may have its greatest impact in controversial cases in which some members of the jury convince others to increase their awards because the insured defendant can afford to pay and will not be seriously injured by a sizeable judgment. ${ }^{110}$

Some evidence suggests that if the topic of insurance is mentioned at trial and the jurors are instructed to disregard that information, they will return a higher award than jurors who do not consider insurance. ${ }^{111}$ The instruction to disregard seems to sensitize jurors to the insurance issue and causes them to award the plaintiff more.

Broeder studied thirty mock juries in automobile negligence cases. Onethird of the jurors were given no information about insurance; their mean compensatory award was $\$ 33,000$. One-third were told about the insurance but given no instruction to disregard this information; their mean award was $\$ 37,000$. The final third were given information about insurance as well as an instruction to disregard that information; their mean award was $\$ 46,000.112$ This finding fits with data suggesting that jurors in criminal trials are influenced by information they have been instructed to disregard. ${ }^{113}$

105. J. Guinther, supra note 8 , at 98 .

106. Id. at 74 .

107. Erlanger, supra note 93 , at 350 .

108. Hans \& Ermann, supra note 15, at 157.

109. J. Guinther, supra note 8 , at 98 .

110. Erlanger, supra note 93 , at 350.

111. Broeder, The University of Chicago Juny Project, supra note 14, at 754.

112. Id.

113. See, e.g., Hans \& Doob, Section 12 of the Canada Evidence Act and the Deliberations of Simulated Juries, 18 Crim. L.Q. 235, 237 (1976): Thompson, Fong \& Rosenhan, Inadmissible Evidence and Juror Verdicts, 40 J. Personality \& Soc. Psychology 453, 457-62 (1981). 
4. The Taxability of Damage Awards. Compensatory awards made to plaintiffs in personal injury and wrongful death cases are generally not taxed.114 Conversely, punitive damage awards and damages to replace lost wages or lost profits represent taxable income. The question whether juries should be instructed as to the taxability of damages awarded is an ongoing controversy. ${ }^{115}$ At this point, exceedingly little is known about the role of tax considerations in jury deliberations. Goodman, Greene, and Loftus asked mock jurors in wrongful death cases to indicate the legal and extra-legal factors they considered in deciding on a damages award. Only 11 percent of them mentioned issues relating to taxation. ${ }^{116}$

5. Prejudgment Interest. The majority of states allow plaintiffs in personal injury cases to receive prejudgment interest to compensate them for the delay between the accident and the time of recovery. ${ }^{117}$ Some juries add a sum to the award to reflect the interest the plaintiff would have earned on money that went instead to cover medical expenses. ${ }^{118}$ What happens in states without this provision? Do jurors intuitively consider the impact of a delay when deciding on a compensatory award?

The answer appears to be yes. Data show that in jurisdictions without prejudgment interest statutes, jurors award extra compensation to plaintiffs whose cases take longer to reach trial. ${ }^{119}$ Hammitt, Carroll, and Relles surmise that juries do not explicitly increase their award to compensate for a delay ${ }^{120}$ (as did jurors in the asbestos case in order to cover attorneys' fees ${ }^{121}$ ). Rather, they evaluate the monetary damages in current, rather than in accident-year dollars. With inflation, prejudgment interest is implicitly built into their calculations. ${ }^{122}$ One caveat is in order: Hammit, Carroll, and Relles did not directly evaluate the processes of decisionmaking in these cases, but evaluated the outcomes of deliberation. Therefore, any conclusions about actual procedures used by juries to deal with this issue must necessarily be speculative.

114. Note, Instructing the Jury on the Taxability of Their Awards-But First, How Are They Taxed?, 9 AM. J. Trial Advoc. 299, 299 (1985).

115. See, e.g., Vasina v. Grumman Corp., 644 F.2d 112, 118 (2d Cir. 1981) (court upheld a trial court decision not to allow a jury instruction with respect to income taxes); Otis Elevator Co. v. Reid, 706 P.2d 1378, 1382 (Nev. 1985) (court held that tax instructions are appropriate only when taxrelated issues in a case increase the likelihood that the jury will consider the tax consequences). $C f$. Norfolk \& W. Ry. Co. v. Liepelt, 444 U.S. 490, 497 (1980), in which the Court favored an instruction on the rationale that the average juror would probably assume an award was taxable not being "aware of the special statutory exception for personal injury awards." The Court argued that without this information, jurors would inflate any award to allow for tax effects and that the instruction would "merely eliminate an area of doubt or speculation." Id. at 498 .

116. Goodman, Greene \& Loftus, supra note 15, at 303.

117. Hammitt, Carroll \& Relles, supra note 20 , at 758 .

118. Rand Corporation, Report on the First Four Years 21 (1984).

119. Hammitt, Carroll \& Relles, supra note 20 , at 759.

120. Id. at 761 .

121. M. Selvin \& L. Picus, supra note 8, at 38-39.

122. Hammitt, Carroll \& Relles, supra note 20 , at 761 . 
Overall, however, jurors apparently often discuss factors on which the judge's instructions were silent: contingency fees, insurance, taxation, and interest payments. These factors are likely to influence the deliberations when the jury is unable to reach a consensus. Jurors apparently raise these silent issues in order to persuade their colleagues to increase (in the case of contingency fees or interest payments) or decrease (when the plaintiff is insured) their awards. Unfortunately, few studies have assessed these possibilities, so it is difficult to know whether jurors' discussions of the silent issues reflect correct understanding of the law or misinformed hunches.

\section{$\mathrm{V}$}

\section{Conclusion}

How able are juries to compensate plaintiffs for their injuries? Are juries unpredictable and capricious in their decisionmaking? Or do damage awards reflect responsible and rational deliberation processes?

The few studies that have evaluated this issue lead to somewhat contradictory conclusions about the processes used to determine damage awards. This inconsistency, combined with the nascent state of the research, suggests that there are no simplistic responses to these queries. However, it is probably safe to assert that in cases where damages are uncontroverted and jury consensus is reached without difficulty, jurors will probably compartmentalize their discussion and consider evidence relevant to various damages discussed at trial (for example, medical expenses, lost wages) rather than use a single-sum approach. Self-report data from jurors suggest that when they determine individual, predeliberation awards, most employ some form of calculation rather than endorse what seems to be a reasonable figure. Further, juries in these cases are likely to reach a consensus by informally considering the range of preferred responses and deriving a figure on which jurors can agree, rather than by explicitly calculating an average or mean award. According to some studies, the figure eventually agreed upon is often close to the amount requested by the plaintiff. (Recall, of course, that jurors deliberating about damages typically will have just concluded their discussions on liability with a decision in favor of the plaintiff.) Other studies suggest that the agreed-upon amount is close to, or greater than (but apparently not less than) jurors' predeliberation awards.

In cases involving more complex evidence or evidence based on uncertain information (for example, expert medical, scientific, or economic testimonyespecially if presented by opposing expert witnesses), and in cases in which jurors cannot easily reach a consensus, a different set of decisionmaking processes may operate. Here, jurors may anchor on an amount suggested by one side or the other, ${ }^{123}$ rather than attempt to perform detailed and complicated calculations themselves. Some jurors may consider the silent factors of contingency fees, insurance, taxation, and interest payments when

123. T. Petzinger, supra note 24 , at 403-04. 
attempting to extract concessions from others. A requirement that the jury reach a unanimous verdict seems to increase the probability that it will discuss these silent factors.

Although very little is known about the ways that jurors determine punitive or exemplary damages, this decision probably involves processes somewhat different from those used to award compensatory damages. Often, jurors have less information relevant to punitive damages than to compensatory damages. For example, in negligence cases, the plaintiff may provide an extremely detailed accounting of his or her medical expenses and losses related to the injury, but may present little or no evidence to inform the jury's decisions about punishment and deterrence. In other cases, the plaintiff may present evidence of the defendant's ability to pay. In both instances, the jury is accorded vast freedom to impose punishment on the defendant and to attempt to deter others, and is often unguided even as to ballpark figures.

Another reason that punitive damage assessments may not mirror compensatory award calculations is that the determination to punish or to deter is decidedly different from the decision to compensate, because it is motivated by different concerns. One study has shown that discussions about punitive damages are more likely to involve normative, value-laden judgments than references to the evidence presented at trial. ${ }^{124}$ This suggests that the process of awarding punitive damages may be driven less by the evidence considered than by the verdict reached, ${ }^{125}$ and that these discussions may be more wide-ranging than is true of compensatory calculations. In fact, it is not clear that jurors routinely calculate punitive damages. Interestingly, punitive awards are often of rounded numbers such as $\$ 100,000, \$ 500,000$ or $\$ 1$ million, suggesting that little calculating may actually take place. Instead, jurors may be more likely to agree on an amount by a process of negotiation: Members of one group raise their award if members of another group lower theirs. Apparently, only if this type of consensus fails will jurors compute an average or mean punitive award.

Are jurors acting responsibly and rationally in these decisions? It is probably too early to know. We do know that juries are occasionally biased against corporate defendants and that they may fuse their sentiments about liability with decisions about damages. We also know that juries occasionally consider factors they had been instructed not to evaluate. On the other hand, it is clear that jurors' reasoning is much more involved and sophisticated than the single-sum approach entails. It is also clear that when unanimity is required, most jurors' opinions are considered and the resulting award often reflects the sentiments of the entire panel. What is perhaps most clear, however, is that our understanding of these issues is in an extremely rudimentary stage and that firm conclusions about the processes involved in damage award determinations will simply have to await the accumulation of evidence.

124. Kaplan \& Miller, supra note 15 , at 310 .

125. R. Hastie, S. Penrod \& N. Pennington, Inside the Jury 163-65 (1983). 